\title{
Cutaneous Squamous Cell Carcinoma of the Head and Neck cN3a TNM Finding v8
}

National Cancer Institute

\section{Source}

National Cancer Institute. Cutaneous Squamous Cell Carcinoma of the Head and Neck cN3a TNM Finding v8. NCI Thesaurus. Code C133221.

Cutaneous squamous cell carcinoma of the head and neck with metastasis in a lymph node larger than $6 \mathrm{~cm}$ in greatest dimension and ENE(-). (from AJCC 8th Ed.) 